\title{
Cough threshold in patients with chronic obstructive pulmonary disease
}

\author{
C H Wong, A H Morice
}

\begin{abstract}
Background-Cough is an important symptom of patients with chronic obstructive pulmonary disease (COPD). The cough threshold to citric acid and capsaicin in patients with COPD and in normal volunteers was measured, as well as bronchial hyperresponsiveness to methacholine.

Methods-Nineteen patients with COPD and 22 controls were recruited. Subjects underwent a methacholine bronchoprovocation test and a cough challenge to citric acid and capsaicin.

Results-The log citric acid cough threshold $\mathrm{D}_{2}$ (concentration causing two coughs) was significantly lower in patients with COPD (mean 2.17 versus 2.56, mean difference $(95 \% \mathrm{CI}) 0.39(0.04$ to 0.74$), \mathrm{p}=$ $0.02)$ but not for capsaicin cough $D_{2}(0.66$ versus $0.8, p=0.41)$. Sixteen patients with COPD had bronchial hyperresponsiveness which was correlated with baseline $\mathrm{FEV}_{1}(\boldsymbol{r}$ $=0.6, \mathrm{p}=0.01,95 \% \mathrm{CI} 0.15$ to 0.84 ).

Conclusions-Patients with COPD have a lower cough threshold to citric acid, possibly due to a differential effect of cigarette smoke on citric acid sensitive cough receptors.
\end{abstract}

(Thorax 1999;54:62-64)

Keywords: chronic obstructive pulmonary disease; cough; bronchial hyperresponsiveness

Cough and breathlessness are common respiratory symptoms of patients with chronic obstructive pulmonary disease (COPD). The definition of chronic bronchitis - namely, daily cough with the production of phlegm for three months for at least two years - emphasises the importance of cough. However, the cough reflex has not been extensively studied in these patients.

Many patients with COPD have hyperreactive airways. ${ }^{12}$ Bronchial hyperresponsiveness in both smokers ${ }^{3}$ and patients with $\mathrm{COPD}^{4}$ is associated with a greater rate of annual decline in forced expiratory volume in one second $\left(\mathrm{FEV}_{1}\right)$. This phenomenon may be explained by airway mechanics ${ }^{5}$ and the underlying pathology. ${ }^{4}$

It has become increasingly clear that the reflex responses of cough and bronchoconstriction, although closely related, are mediated by separate neural pathways. Evidence includes differential stimulation and inhibition of these reflexes by drugs. ${ }^{6-9}$ This study was performed to examine the relationship between the cough threshold and bronchial hyperresponsiveness in patients with COPD.

\section{Methods}

SUBJECTS

Patients with a documented diagnosis of COPD were recruited from the outpatient clinics. Inclusion criteria were a history of smoking, a reduced $\mathrm{FEV}_{1}$ or $\mathrm{FEV}_{1} / \mathrm{FVC} \%$, and less than $15 \%$ reversibility of baseline $\mathrm{FEV}_{1} 15$ minutes after the inhalation of $5 \mathrm{mg}$ nebulised terbutaline sulphate.

Control subjects were recruited by local advertisement and inclusion criteria were nonsmokers, no history or family history of atopy, and normal spirometric values.

The study was approved by the local ethics committee and all subjects gave written informed consent.

\section{COUGH CHALLENGE TEST}

Cough challenge to inhaled citric acid and capsaicin was performed by a method previously described. ${ }^{10}$ Briefly, stock solutions of citric acid $1000 \mathrm{mM}$ and capsaicin $1 \mu \mathrm{M}$ were diluted with $0.9 \%$ saline to produce five log doubling doses of each (citric acid 10, 30, 100, 300, and $1000 \mathrm{mM}$; capsaicin 1, 3, 10, 30, and $100 \mu \mathrm{M})$. Citric acid was administered first and the doses were arranged in ascending order with two doses of saline randomly added in an attempt to preserve patient blinding. The solutions were delivered by a compressed air driven nebuliser controlled by a breath activated Mefar MB3 dosimeter (Mefar, Brescia, Italy). The output of the dosimeter was $0.1 \mathrm{ml} / \mathrm{s}$. The subjects received four inhalations of each dose, each of one second duration, with a 10 second interval between each. The cough response during this interval was recorded. After a 10 minute interval the capsaicin was administered in a similar fashion. Log dose response curves were constructed for each test and the concentration causing two coughs, the cough threshold $\left(\mathrm{D}_{2}\right)$, was calculated by linear interpolation. Subjects who did not achieve a cough threshold were assumed to have a $\mathrm{D}_{2}$ at the highest concentration of the stimulus.

Spirometric tests (Vitalograph, UK) were performed in all subjects before and after the cough challenge.

METHACHOLINE BRONCHOPROVOCATION TEST Methacholine bronchoprovocation testing was performed using a method previously described. ${ }^{11}$ Methacholine was administered in doubling cumulative doses over the range 3.125-6400 $\mu \mathrm{g}$ via the Mefar MB3 dosimeter (Mefar, Brescia, Italy) and Vitalograph Spirotrac software version 2.03 (Vitalograph Ltd, Buckingham, UK). Airway responsiveness was expressed as the dose required to produce a $20 \%$ fall from baseline $\mathrm{FEV}_{1}\left(\mathrm{PD}_{20}\right)$. 
DATA ANALYSIS

The cough data were log transformed and compared using the Student's unpaired $t$ test. The number of subjects in both groups with bronchial hyperresponsiveness was compared using Fisher's exact test. The correlation coefficient was used to examine the relationship between the $\mathrm{FEV}_{1} \%$ predicted and $\mathrm{PD}_{20}$. Statistical significance was assumed at a $\mathrm{p}<0.05$ level.

\section{Results}

Nineteen patients (13 men) of mean age 59 years (range 30-77 years) with COPD and 22 control subjects ( 16 men) of mean age 55 years (range 29-74) were recruited. The patients with COPD had a mean smoking history of 35 pack years (range 10-80) and had a 5\% mean improvement of $\mathrm{FEV}_{1}$ with $5 \mathrm{mg}$ nebulised terbutaline sulphate.

Patients with COPD had a mean (SD) $\mathrm{FEV}_{1}$, $\mathrm{FEV}_{1} \%$ predicted, and $\mathrm{FEV}_{1} / \mathrm{FEV} \%$ of 1.75 (0.59) litres, 59.8 (20.5)\%, and 61.9 (11.2)\%, respectively. Values for the control group were 3.43 (0.81) litres, 104.4 (12.6)\%, and 80 (6.8)\%, respectively.

Sixteen patients with COPD demonstrated bronchial hyperresponsiveness to methacholine (as defined by a fall of at least $20 \%$ in $\mathrm{FEV}_{1}$ to less than $6.4 \mathrm{mg}$ methacholine) compared with two of the 22 control subjects $(\mathrm{p}<0.0001)$.

The mean (SD) log citric acid cough $\mathrm{D}_{2}$ was significantly decreased in patients with COPD compared with controls $(2.17$ (0.68) and 2.56 (0.42), respectively; mean difference $(95 \% \mathrm{CI})$ 0.39 (0.04 to 0.74$) ; p=0.02$ ). In contrast, the values for capsaicin were not significantly different $(0.66(0.57)$ and $0.8(0.55)$ in patients with COPD and controls, respectively; $\mathrm{p}=$ 0.41 ; fig 1 ).

In the 16 patients with bronchial hyperresponsiveness there was a significant correlation between the baseline $\mathrm{FEV}_{1} \%$ and the level of bronchial hyperresponsiveness $(r=0.6, \mathrm{p}=$ $0.01,95 \%$ CI 0.15 to 0.84 ).

The relationship of the $\mathrm{PD}_{20}$ to methacholine was compared with both citric acid and capsaicin cough $\mathrm{D}_{2}$ in patients with COPD. No significant correlation was found in either group.

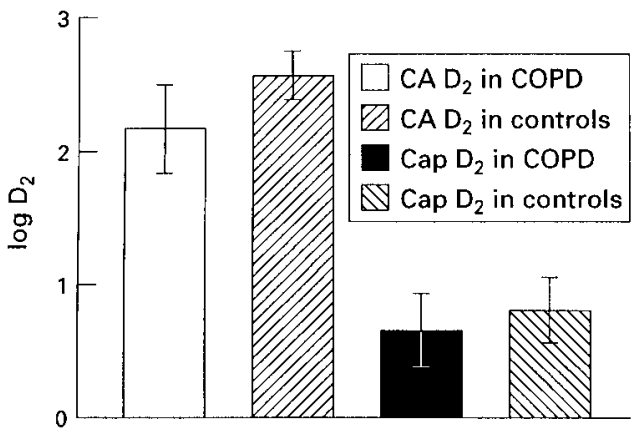

Figure 1 Mean log citric acid (CA) and capsaicin (Cap) cough thresholds $\left(D_{2}\right)$ in patients with COPD and controls (with $95 \%$ confidence intervals).

\section{Discussion}

Cough is a common symptom in patients with COPD. Cough challenge testing is used to examine many aspects of the cough reflex but few studies have applied this test in patients with COPD. In one of the earliest reports Taylor et al demonstrated a lower cough threshold to citric acid in those smokers who inhaled their cigarette more deeply. ${ }^{12}$ In a more recent study Auffarth et $a l^{13}$ found no difference in the citric acid cough threshold between asthmatic subjects and those with COPD, and there was no correlation between the cough threshold and non-specific bronchial responsiveness to histamine. Our study is the first to our knowledge to compare directly cough thresholds between patients with COPD and normal subjects. We found a significantly lower cough threshold to citric acid in patients with COPD but not to capsaicin. As part of a study of patients with chronic cough, Choudry et al included 11 patients with COPD ${ }^{14}$; the cough threshold to capsaicin in these patients was not significantly different to controls.

We believe that citric acid and capsaicin stimulate cough through different mechanisms. Citric acid stimulates the rapidly adapting receptors (RARs or irritant receptors) located in the larynx and upper airways of the tracheobronchial tree to cause cough, ${ }^{15}$ whereas capsaicin may cause cough through stimulation of the C fibres via non-selective ion channels. ${ }^{16}$ The cough challenge results in this study support this hypothesis. In patients with COPD smoking may have a differential effect on citric acid sensitive receptors. One explanation may be the differential deposition of cigarette smoke in the airways. Larger particle aerosols at high inhalation flow rates tend to be deposited in central airways by inertial impaction. ${ }^{17}$ Cigarette smoke may be deposited on the more central airways where the citric acid sensitive cough receptors are more abundant. ${ }^{15}$ Laryngeal inflammation in COPD may play a part since we have observed a decrease in citric acid induced cough compared with capsaicin induced cough in patients who have had a laryngectomy. ${ }^{18}$

Cough and bronchoconstriction are now considered to be separate airway reflexes. In asthmatic subjects, cough but not bronchoconstriction, is caused by solutions of low chloride ${ }^{6}$ and non-isomolar solutions cause bronchoconstriction but not cough. ${ }^{6}$ Inhaled anaesthetics inhibit distilled water induced cough but not bronchoconstriction. ${ }^{7}{ }^{9}$ Drugs such as atropine and sodium cromoglycate inhibit bronchoconstriction but not cough. ${ }^{89}$ The lack of correlation between cough threshold and bronchial hyperresponsiveness in asthmatic patients, those with COPD and normal subjects ${ }^{12}{ }^{13}$ is further evidence. Our study confirms this relationship also.

Non-specific bronchial hyperresponsiveness is a characteristic feature of asthma but it is also seen in patients with COPD. The described incidence varies from $46 \%$ to $100 \% .{ }^{12}$ In this study $84 \%$ of the COPD patients had bronchial hyperresponsiveness to methacholine. We observed an increased degree of bronchial 
hyperresponsiveness as the predicted $\mathrm{FEV}_{1}$ decreased, a relationship that has been well described. ${ }^{120}$

In summary, we have found a lower citric acid cough threshold in patients with COPD which may be due to the effect of cigarette smoke on citric acid sensitive receptors in the larynx and upper airways.

1 Yan K, Salome CM, Woolcock AJ. Prevalence and nature of bronchial hyperresponsiveness in subjects with chronic obstructive pulmonary disease. Am Rev Respir Dis 1985;132:25-9.

2 Tashkin DP, Altose MD, Bleecker ER, et al. The lung health study: airway responsiveness to inhaled methacholine in smokers with mild to moderate airflow limitation. Am Rev Respir Dis 1992;143:301-10.

3 Frew AJ, Kennedy SM, Chan-Yeung M. Methacholine responsiveness, smoking and atopy as risk factors for accelerated FEV, decline in male working populations. Am Rev Respir Dis 1992;146:878-83.

4 Tashkin DP, Altose MD, Connett JE, et al. Methacholine reactivity predicts changes in lung function over time in smokers with early chronic obstructive pulmonary disease. Am $\mathcal{F}$ Respir Crit Care Med 1996;153:1802-11.

5 Moreno RH, Hogg JC, Pare PD. Mechanics of airway narrowing. Am Rev Respir Dis 1986;133:1171-80.

6 Eschenbacher WL, Boushey HA, Sheppard D. Alteration in osmolarity of inhaled aerosols cause bronchoconstriction and cough, but absence of a permeant anion causes cough alone. Am Rev Respir Dis 1984;129:211-5.

7 Choudry NB, Fuller RW, Anderson N, et al. Separation of cough and reflex bronchoconstriction by inhaled local anaesthetics. Eur Respir f 1990;3:579-83.
8 Fuller RW, Collier JG. Sodium cromoglycate and atropine block the fall in FEV, but not the cough induced by hyperblock the fall in $\mathrm{FEV}_{1}$ but not the co
tonic mist. Thorax 1984;39:766-70.

9 Sheppard D, Rizk NW, Boushey HA, et al. Mechanism of cough and bronchoconstriction induced by distilled water aerosol. Am Rev Respir Dis 1983;127:691-4.

10 Morice AH, Higgins KS, Yeo WW. Adaptation of the cough reflex with different types of stimulation. Eur Respir F 1992; 5:841-7.

11 Gordon SB, Curran AD, Turley A, et al. Glass bottle workers exposed to low dose irritant fumes cough but do not wheeze. Am $\mathcal{F}$ Respir Crit Care Med 1997;156:206-10.

12 Taylor DM, Reid WD, Pare PD, et al. Cigarette smoke inhalation patterns and bronchial reactivity. Thorax 1988;43: lation pat $65-70$.

13 Auffarth B, de Monchy JGR, van der Mark TW, et al. Citric acid cough threshold and airway responsiveness in asthmatic patients and smokers with chronic airflow obstruction. Thorax 1991;46:638-42.

14 Choudry NB, Fuller RW. Sensitivity of the cough reflex in patients with chronic cough. Eur Respir f 1992;5:296-300.

15 Boushey HA, Richardson PS, Widdicombe JG, et al. The response of laryngeal afferent fibres to mechanical and chemical stimuli. Physiology 1974;240:153-75.

16 Bevan S, Docherty RJ. Cellular mechanisms of action of capsaicin. In: Wood J, ed. Neurosciences perspective: capsaicin in the study of pain. New York: Academic, 1993;27-44.

17 Brain JD, Valberg PA. Deposition of aerosol in the respiratory tract. Am Rev Respir Dis 1979;120:1325-72.

18 Turley AJ, Morice AH.The effect of total laryngectomy on the cough reflex in human subjects. Eur Respir $\mathcal{f}$ 1995;8:307s.

19 Fujimura M, Sakamoto S, Kamio Y, et al. Cough receptor sensitivity and bronchial responsiveness in normal and asthmatic subjects. Eur Respir F 1992;5:291-5.

$20 \mathrm{Du}$ Toit JI, Woolcock AJ, Salome CM, et al. Characteristics of bronchial hyperresponsiveness in smokers with chronic air-flow limitation. Am Rev Respir Dis 1986;134:498-501. 